\title{
Trade Agreements and Services Value Chain: The Case of India and Thailand
}

\author{
Tanu M Goyal ${ }^{1} \&$ Arpita Mukherjee ${ }^{2}$ \\ ${ }^{1}$ Consultant, Indian Council for Research on International Economic Relations (ICRIER), New Delhi, India. \\ ${ }^{2}$ Professor, ICRIER, New Delhi, India. \\ Correspondence: Arpita Mukherjee, Professor, ICRIER, New Delhi, India.
}

Received: June 29, 2016

doi:10.11114/afa.v3i1.1840
Accepted: August 3, 2016

Available online: August 26, 2016

\begin{abstract}
Services sector is an important component of the world trade and production networks. With the opening up of world economy, the role of services in the global value chain and value added has expanded. Services liberalisation is becoming a crucial component of free trade agreements. This is particularly true for trade agreements between South and Southeast Asia. Given this background, the objective of this paper is to understand the scope of establishing services value chain between two countries in South and Southeast Asia - namely India and Thailand - by integrating the two markets through trade agreement. The analysis is based on secondary data, in-depth interviews with policy makers and stakeholders in India and Thailand and an examination of the existing trade agreements of the two countries. The paper found that the present level of integration between the two markets is low due to the existence of market access barriers and regulatory bottlenecks. The paper makes recommendation on how the two countries can reduce barriers to trade in services, thereby fostering greater integration and leveraging the development of a global value chain.
\end{abstract}

Keywords: value chain, services sector, trade agreements, India, Thailand, Asia

\section{Introduction}

Globalisation, technological development and liberalisation have led to an increase in international trade and establishment of global production networks and services value chains. Services value chains can be broadly of two types. In the first type, services such as logistics services help to increase the global competitiveness of manufacturing through faster end-to-end reliable transportation of goods. In the second type there are services such as information technology (IT) and IT enabled services (ITeS), which can be outsourced to low cost destinations, thereby leading to the establishment of services value chain. Thus, the services value chain can be linked to the goods production network or they can develop on their own with technological development and establishment of new business models.

Whatever may be the type of the services value chain there is no doubt that services sector today is a growing component of global trade and investment. It has also become an integral part of the trade negotiations during the Uruguay Round of the World Trade Organization (WTO) negotiations (1986-1994), which established a framework for the services negotiations, known as the General Agreement on Trade in Services (GATS). The slow process of the second round of the WTO negotiations - the Doha Round - led to a sudden surge in bilateral and regional trade arrangements. Since the last decade there has been a trend towards comprehensive trade agreements which include trade in goods, trade in services, bilateral investment flows and a range of other issues such as customs co-operation and trade facilitation. These agreements have supported the developments of cross-country value chains.

South and Southeast Asia have often been referred to as the noodle bowl of free trade agreements (see Baldwin 2006 and Kawai and Wignaraja 2009). ${ }^{1}$ In the past 15 years, South and Southeast Asian countries have signed several comprehensive free trade agreements (FTAs). These include the India-Singapore Comprehensive Economic Cooperation Agreement (CECA), Thailand-Australia FTA, the Association of South East Asian Nations (ASEAN), to name a few. The ASEAN (Brunei, Burma (Myanmar), Cambodia, Indonesia, Laos, Malaysia, Philippines, Singapore,

\footnotetext{
1 A diagrammatic representation of the Asia-Pacific Noodle Bowl is available at http://www.unescap.org/sites/default/files/Asia-Pacific\%20Noodle\%20Bowl.pdf (accessed on June 8 2016)
} 
Thailand, Vietnam) along with Australia, China, India, Japan, South Korea and New Zealand are negotiating the Regional Comprehensive Economic Partnership Agreement (RCEP), which is likely to be the largest trade agreement in Asia. The services sector has been a key component of the comprehensive agreements that have been signed and will be a key component of the agreements which are now being negotiated, including the RCEP. It is expected that the bilateral and regional trade agreements will lead to further liberalisation of trade in services and integration of the services market.

Given this background, this paper looks at how trade agreements can help to strengthen the services value chain, taking the example of India and Thailand. Thailand and India are engaged in negotiation of bilateral comprehensive trade agreement which includes trade in services. They are part of the trade agreement in services signed between India and ASEAN and are now negotiating the RCEP. These two countries have different comparative advantages in services, which can be leveraged through trade agreements.

The layout of the paper is as follows: Section 2 presents a review of the literature and the research methodology followed in the paper. Section 3 examines the secondary data looking at the share of India and Thailand in global trade in services, their comparative advantages and trade complementarities. It also examines the bilateral trade and investment flows. It further presents the data on trade in value added in total exports and exports of manufacturing for India and Thailand using secondary data. Section 4 presents the foreign direct investment (FDI) policy of the two countries and its role in market integration. Section 5 looks at three types of connectivity - physical connectivity, people-to-people connectivity and institutional connectivity, and how the connectivity can be strengthened in the case of India and Thailand to support market integration and development of value chains. Section 6 focuses on barriers to market integration and development of value chains. Section 7 highlights how commitments under trade agreements can go beyond the level of autonomous liberalisation and thereby facilitate market integration and development of services value chain and Section 8 presents the main conclusions.

\section{Literature Review and Research Methodology}

Traditionally, production of goods was divided in two stages-raw materials and finished goods (Ohlin, 1933). With technological developments and the liberalisation of world economies, production is being fragmented and the concept of global value chains has emerged (De Backer and Miroudot, 2013). This has led to the development of distinct services activities within the global value chain of goods (Brockman and Stephenson, 2012; López et al., 2011).

The composition of services in the value of tradable has been increasing over time. According to the WTO (2014), trade in value added show that services take a more pronounced role in international trade. Services such as logistics services help to increase the global competitiveness of manufacturing through faster end-to-end reliable transportation of goods. In addition, with increasing use of information technology (IT), the rise in outsourcing of services and the development of new business models, the services value chain has evolved to complement the global production networks (Rubalcaba et al., 2011; World Economic Forum, 2012).

Studies have highlighted that fostering connectivity between India and countries in Southeast Asia will not only reduce the service-linked cost of trading goods but also accelerate the development of manufacturing, production networks and value chains. There are broadly three types of connectivity - institutional connectivity, people-to-people connectivity and physical connectivity (Kimura et. al., 2011). Studies have also highlighted that cross-country connectivity can be fostered through liberalisation of services trade, either autonomously or through trade agreements (United Nations, 2014). As a result, it is important to understand how liberalisation of services through trade agreements can enable the creation of a services value chain.

This paper is based on secondary data analysis and in-depth interviews with policy makers and other stakeholders in India and Thailand. An issue with analysing the potential in trade in services is related to inadequacy of data. In India, like most other countries it is difficult to obtain bilateral, mode-wise data on trade in services. As a result, to understand the trade interest in each other's markets, secondary data was supported by in-depth interviews with policy makers and industry in both the countries. Around 35 interviews were held both in India and Thailand to understand the trade interest and potential in the two markets. To assess the negotiating strategies of the two countries, the architectural design of the trade agreements of India and Thailand is analysed, using the Fink and Molinuevo (2008) approach to assess the scheduling approach, definitions and coverage of the concluded trade agreements of India and Thailand. Based on the above, the potential for developing a services value chain between India and Thailand is examined.

\section{An Examination of the Secondary Data}

This section analyses the secondary data available for India and Thailand. It studies the overall and bilateral trends and patterns in trade and investment in services followed by an examination of the information on trade in value added. 


\subsection{Trends and Patterns in Trade and Investment}

In 2014, India was ranked the $8^{\text {th }}$ largest exporter and importer of services with a share of 3.2 percent and 3.1 percent respectively in the world's exports and imports of commercial services among the WTO member countries. Thailand, with a share of 1.1 percent in the world's exports and imports, had the rank of $24^{\text {th }}$ and $28^{\text {th }}$ respectively in the same year. Both India and Thailand had a positive balance in trade in services; however, the balance for India was higher than for Thailand (Table 1). India has a positive balance in a number of services sectors. In sectors such as personal, cultural and recreational services Thailand enjoys a positive trade balance while India is a net importer. Table 1 clearly shows that there is scope for bilateral trade in services given the trade complementarities between the two countries.

Table 1. India and Thailand Global Trade in Services in 2015 (in US\$ Million)

\begin{tabular}{lcccc}
\hline Category & \multicolumn{2}{c}{ India } & \multicolumn{2}{c}{ Thailand } \\
& Exports & Imports & Exports & Imports \\
\hline Services & 155839.51 & 123111.24 & 60643.25 & 50779.33 \\
Goods-related services & 319.35 & 287.70 & - & - \\
Transport & 14343.46 & 52294.52 & 5715.34 & 23817.08 \\
Travel & 21014.35 & 14851.55 & 44521.21 & 7587.97 \\
Other services & 120162.35 & 55677.47 & 10406.69 & 19374.28 \\
Construction & 1486.04 & 965.79 & 530.23 & 845.14 \\
Insurance and pension services & 1987.45 & 5304.84 & 57.00 & 2356.01 \\
Financial services & 5330.90 & 3099.74 & 203.10 & 223.03 \\
Charges for the use of intellectual property n.i.e. & 463.62 & 5006.78 & 180.63 & 4104.54 \\
Telecommunications, computer, and information & 57661.03 & 3781.98 & 448.75 & 588.82 \\
services & & & & \\
Other business services & 48613.55 & 29906.32 & 8566.27 & 10920.96 \\
Personal, cultural, and recreational services & 1261.96 & 1388.28 & 57.58 & 29.42 \\
Government goods and services n.i.e. & 551.26 & 886.23 & 363.14 & 306.35 \\
Memo item: Commercial services & 155288.25 & 122225.01 & 60280.11 & 50472.98 \\
\hline
\end{tabular}

Note: The highlights show the sectors with positive trade balance. The trade data presented here follows the Balance of Payment Manual 6 (BPM6) classification of services. This is different from the BPM5 classification as it clubs together sectors such as telecommunications, computers and information services, which were originally disaggregated. As a result, it is not possible to assess the individual sector contribution for this level of disaggregation.

Source: Extracted from United Nations Conference on Trade and Development (UNCTAD) Statistics available at http://unctad.org/en/Pages/Statistics.aspx (accessed on June 10, 2016)

To understand the comparative advantages of the two countries, Revealed Comparative Advantage (RCA) ${ }^{2}$ scores of the two countries are given below.

\footnotetext{
${ }^{2}$ Revealed Comparative Advantage (RCA) is used to examine and assess the pattern and specialisation of a country and therefore its global competitiveness in a particular sector vis-à-vis the rest of the world. To analyse the export competitiveness of different services of India and Thailand vis-à-vis the rest of the world, we used the Balassa index. The formula is:

$\mathrm{RCA}_{\mathrm{ij}}{ }^{2}=\left(\mathrm{x}_{\mathrm{ij}} / \mathrm{X}_{\mathrm{it}}\right) /\left(\mathrm{x}_{\mathrm{wj}} / \mathrm{X}_{\mathrm{wt}}\right)$ where $\mathrm{x}_{\mathrm{ij}}$ and $\mathrm{x}_{\mathrm{wj}}$ are the values of a country's exports of services sector $\mathrm{j}$ and the world's exports of services sector $\mathrm{j}$, and $\mathrm{X}_{\mathrm{it}}$ and $\mathrm{X}_{\mathrm{wt}}$ refer to the country's total exports and world total exports.
} 
Table 2. RCA for India and Thailand for Different Services Sector in 2015

\begin{tabular}{lcc}
\hline Sector & India & Thailand \\
\hline Transport & 0.51 & 0.52 \\
Travel & 0.53 & 2.88 \\
Other services & 1.45 & 0.32 \\
Construction & 0.52 & 0.47 \\
Insurance and pension services & 0.50 & 0.04 \\
Financial services & 0.40 & 0.04 \\
Charges for the use of intellectual property n.i.e. & 0.05 & 0.05 \\
Telecommunications, computer, and information services & 3.78 & 0.08 \\
Other business services & 1.45 & 0.66 \\
Personal, cultural, and recreational services & 0.98 & 0.11 \\
Government goods and services n.i.e. & 0.24 & 0.40 \\
Memo item: Commercial services & 1.01 & 1.01 \\
\hline Sor
\end{tabular}

Source: Calculated by authors using the Balassa index and data extracted from UNCTAD Statistics available at http://unctad.org/en/Pages/Statistics.aspx (accessed on June 10, 2016)

India and Thailand have comparative advantage in different services sectors. For instance, while Thailand has an advantage in travel services, India has a comparative advantage in telecommunications, computer and information services and other business services. This implies, the two countries certainly have trade complementarity and therefore trade potential in the services sector.

An analysis of India-Thailand bilateral trade in services is limited by the lack of data on bilateral trade in services. The Reserve Bank of India has the data but does not publish it. The data provided by Bank of Thailand is available for only two years - 2009 and 2010. In 2009, bilateral services trade was valued at \$692 million, but in 2010 it declined to \$520 million. However, Thai imports from India have increased-from \$127 million in 2009 to \$132 million in 2010. Further, the information provided by the Bank of Thailand shows that over the years, the trend in bilateral trade in services between India and Thailand has changed. In 1990 and in 2000, Thailand had a negative trade balance with India, but this was reversed in 2010.

Overall, the bilateral trade in services data is outdated and the non-availability of bilateral trade data for the past few years makes it difficult to examine the recent trends and developments. The Directorate General of Commercial Intelligence and Statistics (DGCI\&S), under the Ministry of Commerce and Industry, India, is trying to develop a framework for collection of statistics on bilateral trade in services and it is trying to conduct enterprise surveys which will help to get information on bilateral trade in selected sector such as medical value travel, audio-visual services and logistics. Unless, there is a comprehensive enterprise survey covering all key services sectors/sub-sectors, the information on bilateral trade flows will be limited.

As regards investment, the data provided by the Department of Industrial Policy and Promotion, Government of India, shows that between April 2000 and March 2016, cumulative FDI from Thailand to India was \$245.15 million making it the $35^{\text {th }}$ investor in India with a share of only 0.08 percent in India's total FDI inflows. Thai investments in India are mainly in sectors such as infrastructure, real estate, food processing, chemicals, and hotel and hospitality sector. ${ }^{3}$

Indian investment in Thailand between July 2007 and June 2015 was about $\$ 404.8$ million with a share of 0.18 percent of India's total overseas investments during that period. The key sectors for investment included agricultural products, minerals and ceramics, metal products and machinery, electrical and electronic products and chemicals and textiles and the share of services sector was pretty low. ${ }^{4}$

\subsection{Trade in Value Added and Creation of Value Chain - India and Thailand}

As per the WTO's International Trade Statistics ${ }^{5}$ between 1995 and 2011, most developed and developing countries significantly increased their contributions to global value chains, resulting in a geographically more diverse manufacturing base. In 2011, nearly half (49 percent) of the world's trade in goods and services took place within global value chain, up from 36 percent in 1995. The database by the Organization of Economic Cooperation and Development (OECD) and WTO on Trade in Value Added (TiVA) reveals that services represent around 70 percent of the trade in

\footnotetext{
${ }^{3}$ For details see http://dipp.nic.in/English/Publications/FDI_Statistics/2016/FDI_FactSheet_JanuaryFebruaryMarch2016.pdf (accessed on June 8 2016) and http://www.mea.gov.in/Portal/ForeignRelation/Thailand_11_01_2016.pdf (accessed on April 22 2016).

${ }^{4}$ Reserve Bank of India and http://www.mea.gov.in/Portal/ForeignRelation/Thailand_11_01_2016.pdf (accessed on April 22 2016).

5 https://www.wto.org/english/res_e/statis_e/its2002_e/its2002_e.pdf (accessed on May 30, 2016).
} 
intermediate inputs and over 30 percent of the total value added in manufacturing goods.

Value added by services in India's and Thailand's global exports and exports to each other has increased steady over the last few years (see Table 3). However, the total value added by services in India's export to the world is higher than that of Thailand. The global exports of India in 2011 were about $\$ 442$ billion and for Thailand they amounted to $\$ 270$ billion. $^{6}$ Taking that in account, the share of value added in services in India's gross exports was about 58.3 percent and for Thailand about 39.5 percent in 2011. In the case of bilateral trade, the value added by services in Thailand's exports to India is higher than that of Indian exports to Thailand.

Table 3. Value added by Services in Gross Total Exports of India and Thailand (in US\$ Million)

\begin{tabular}{ccccc}
\hline $\begin{array}{c}\text { Exporting Country } \\
\text { Year/Partner }\end{array}$ & World & India & \multicolumn{2}{c}{ Thailand } \\
Thailand & 27.014 & 33961.994 & 83.738 \\
2000 & 18805.716 & 27.66 & 33515.141 & 187.272 \\
2005 & 30182.188 & 99.229 & 51517.741 & 413.261 \\
2008 & 87931.299 & 224.49 & 83919.998 & 931.119 \\
2009 & 163977.685 & 247.28 & 75016.126 & 811.322 \\
2010 & 150290.323 & 401.71 & 90617.804 & 1197.163 \\
2011 & 212052.65 & 537.671 & 106819.296 & 1525.717 \\
\hline
\end{tabular}

Source: OECD-WTO TiVA Database accessible at https://stats.oecd.org/index.aspx?queryid=66237 (accessed on May 15 2016)

As regards the value added by services in manufacturing exports, both India and Thailand have registered a remarkable increase. Just as in the case of gross total exports, in the case of exports of manufacturing sector also the services value for India's export to the world is greater than that of Thailand. However, in the case of bilateral trade, value added by Thailand's services sector in manufacturing exports to India is greater than the value added by India's services sector in manufacturing exports to Thailand (see Table 4).

Table 4. Value added by Services in Gross Exports of Manufacturing Sector of India and Thailand (in US\$ Million)

\begin{tabular}{ccccc}
\hline $\begin{array}{c}\text { Exporting Country } \\
\text { Year/Partner }\end{array}$ & World & India & \multicolumn{2}{c}{ Thailand } \\
World & Thailand & 20.854 & 13334.885 & 66.011 \\
2000 & 6074.442 & 18.239 & 14771.61 & 131.538 \\
2005 & 8625.787 & 66.868 & 24498.898 & 288.869 \\
2008 & 23755.016 & 157.324 & 39920.66 & 647.92 \\
2009 & 44088.85 & 182.708 & 35436.697 & 583.691 \\
2010 & 44692.044 & 260.64 & 43765.167 & 867.764 \\
2011 & 62482.185 & 374.182 & 50030.975 & 1054.967 \\
\hline
\end{tabular}

Source: OECD-WTO TiVA Database accessible at https://stats.oecd.org/index.aspx?queryid=66237 (accessed on May 15 2016)

The above data reveals that services are becoming an important component of overall trade per se. As mentioned earlier, while services such as IT and ITeS services have helped to develop services value chains certain services such as logistics and telecommunications services have a stronger role in trade integration. The latter type of services is often embedded in the trade in goods and hence is an inseparable part of the production network. Further, as companies have started establishing operations across countries, efficiency and global competitiveness in the delivery of services is gaining prominence.

\section{FDI Policy and Market Integration}

Domestic policy plays a key role in improving efficiency and competitiveness and in fostering market integration. Within the domestic policy, the FDI policy plays a key role in market integration. Global companies tend to work with their preferred services providers. As companies establish presence across countries, they would like their preferred service providers to be a part of their value chain. This can be possible only when countries remove market access and other barriers to cross-country service provisions.

Both India and Thailand have a fairly restrictive FDI regime in services. The growth of the services sector in the two

\footnotetext{
${ }^{6}$ The data is extracted from WTO International Trade Statistics, 2012 accessible at https://www.wto.org/english/res_e/statis_e/its2012_e/its2012_e.pdf (accessed on May 15 2016).
} 
countries is linked to reforms and liberalisation that the countries initiated in the 1990s. In India, service sector reforms have been part of the overall economic reform process that began in the early nineties due to the balance of payments crisis. India took assistance from the International Monetary Fund (IMF) and, as part of the conditions, it embarked on an ambitious reform process. The core features of the reform were dismantling public monopoly in sectors such as air transport, telecommunications and financial services and allowing private and foreign investment. Most services have been liberalised in a phased manner. Except for a few services sectors such as multi-brand retail, legal, postal, banking, insurance and railways, where there are full or partial FDI restrictions, almost all the other services sectors have been opened up for foreign investment. Public-private partnerships have been encouraged in several sectors, especially infrastructure services, to improve efficiency, productivity, quality of services and global competitiveness. The government is in the process of streamlining rules and regulations in the services sector to facilitate foreign and domestic investment. Despite the liberalisation, services sector continues to face FDI and other regulatory restrictions in India.

Thailand also started liberalising its services sector in the 1990s when it faced the Asian financial crisis in 1997. To tackle the crisis, the Thai government implemented a comprehensive economic reform programme that was part of its IMF loan conditions and focused on macro-economic stabilisation and structural reforms in the corporate and financial sectors. As part of the IMF package requisites, the government opened up the financial sector (with full ownership of 100 percent) to foreign nationals for 10 years. The retail sector was also opened up for foreign investment. Several laws such as the Bankruptcy Law (1940) and the Foreign Business Act, B.E. 2542 (A.D.1999) were amended or passed in 1999. The government also began the deregulation of state-owned enterprises in state-dominated utilities such as telecommunications, transportation, water and energy. However, as of date compared to India, Thailand has a more restrictive regime for foreign investment in services. ${ }^{7}$ Foreign investment is governed by the Foreign Business Act, B.E. 2542 (A.D.1999), which gives a negative list of sectors for investment and allows up to 49 percent foreign ownership.

Overall, the restrictive FDI regime of India and Thailand acts as a major entry barrier for foreign firms, restricting their ability to develop value chains. Along with the FDI restrictions, there are restrictions on movement of people and there are other regulatory barriers which make it difficult to establish an efficient services value chain. Before one examines the barriers we will focus on how the services sector can support market integration and development of value chains.

\section{The Role of Services in Market Integration and Development of Value Chains}

Services can foster market integration and development of value chains through three broad types of connectivity: physical connectivity, people-to-people connectivity and institutional connectivity. In this section we focus on the role of different services sectors in fostering market integration between India and Thailand through the three types of connectivity.

The analysis in this section is based on secondary literature, in-depth interviews with policymakers in India and Thailand and one-to-one meetings with 15 Indian companies and 10 companies from Thailand in the year 2014-15. During the interviews, policymakers and industry from the two countries opined that the bilateral trade in services between India and Thailand is low, but there is potential to increase the trade. Survey participants from the industry felt that a stable political and social condition, and gross domestic product (GDP) growth will support cross-country trade and investment. There is scope for companies from India and Thailand to leverage on their complementarities and jointly explore third country markets. Policymakers and the industry pointed out that both countries have restrictive FDI regime and to benefit from the RCEP Agreement, they need to implement a series of domestic reforms in the services sector. Certain services sub-sectors were identified by the survey participates which can help to develop cross-country value chains. These include transport, telecommunications, IT and ITeS services, and professional services. Some of these are discussed below:

\subsection{Physical Connectivity}

There is a wide range of literature which highlights that physical connectivity in terms of good logistics network and other infrastructure connectivity such as telecommunications network is crucial for integrating the South and Southeast Asian markets and developing production networks and services value chains (see Asian Development Bank (ADB), 2008, 2009; De, 2011; Kimura et al., 2011).

5.1.1 Transport connectivity - Land route from India to ASEAN is through Thailand, where Myanmar plays an important role. The two main links connecting India and Thailand are:

India-Myanmar-Thailand Trilateral Highway (IMTTH): India can be connected to Thailand by road from the northeast of India through Myanmar. The IMTTH is a cross-border transportation network being financed by the Governments of

\footnotetext{
${ }^{7}$ Sally (2005).
} 
India, Myanmar and Thailand. It links Moreh (in Manipur, India) with Mae Sot (in Tak, Thailand) through Bagan (in Mandalay, Myanmar).

Mekong-India Economic Corridor (MIEC): The corridor will link Chennai (India) with Bangkok (Thailand) through Dawai port (Myanmar). MIEC will be an extension of the Southern Economic Corridor from Myanmar and Thailand to other ASEAN countries such as Cambodia and Vietnam.

The survey found that India and Thailand have to develop their domestic transport and logistics infrastructure to benefit from these two projects. Specifically, for the trilateral highway, there is a need for greater connectivity between the northeast regions in India with the rest of the country. At present, northeast India is connected with the rest of India through a 26-kilometre road from Siliguri that is called Chicken's Neck. Development of this highway faces problems such as land acquisition and state government clearances. There is a need for developing the northeast connectivity in India. Further, if India has to integrate with the ASEAN market, it should develop dedicated freight corridors, especially the Chennai-Kolkata Corridor.

Survey participants also said that India should focus on developing two hub ports — one on the west coast and the other on the east coast - and link them through dedicated freight corridors if the country wants to be a part of the global production network.

The survey found that there is potential for India-Thai joint ventures in transport and logistics projects through a public-private partnership (PPP) model. Thailand is strategically located to become a trans-shipment hub between South Asia, Southeast Asia and East Asia. If the country can be connected with Myanmar through the land route, it can become an important channel of transportation between China, India and the CMLV countries (Cambodia, Myanmar, Laos and Vietnam) as well as with Malaysia and Singapore.

Telecommunication connectivity is another key sector for market integration. India and ASEAN are already co-operating in several communication projects including satellite tracking and broadband connectivity. The survey found that the telecommunications sectors in India and Thailand are at different levels of development. In Thailand, the majority of the infrastructure is still owned and controlled by the government and the telecommunications sector works on a build-transfer-operate (BTO) model where the infrastructure is created by the private sector and then transferred to the government. In India, while incumbent government companies play a key role in basic telecommunications, mobile telecommunications has a strong private presence. Compared to Thailand, the foreign investment and regulatory regime in India is more open.

At present, there is a limited presence of Thai and Indian companies in each other's market. While there are some Indian companies such as IDEA Cellular Limited and Bharti Enterprises that have invested in Thailand, there are no Thai companies in India in the telecommunications sector. The Thai telecommunications market is quite saturated and Indian companies feel that investment opportunities are limited.

Survey participants pointed out that call rates between India and Thailand are high, internet penetration in the two markets is low, broadband connectivity is poor and both countries have not subscribed fully to the WTO Reference Paper on Telecommunications that aims to establish a sound regulatory regime. They felt that there is a potential for developing telecommunications infrastructure connecting the two markets. Specifically, they referred to the scope for broadband connectivity through Myanmar or an undersea cable from India connecting the Andaman and Nicobar Islands to the southern Islands in Thailand, such as Phuket and Krabi. It was also pointed out that Indian companies have potential in software development and could jointly work with Thai telecommunications companies in telecommunications-related research and development $(\mathrm{R} \& \mathrm{D})$ software programming and maintenance.

IT and ITeS play a key role in market integration and development of value chains. This is the most important component of India's global services exports and India is one of the key players in developing global value chains in this sector. The survey found that Indian companies are now moving up the value chain to high-end services and are focusing on market diversification and expansion of their products and services. After India signed the comprehensive economic cooperation agreement (CECA) with Singapore, several Indian IT companies have established their base in Singapore to cater to ASEAN countries including Thailand on a project basis. Thailand is not a major IT/ITeS services exporter, but the domestic market is large and less saturated than other ASEAN countries. Often, an Indian company's entry in Thailand is due to the presence of its global client in Thailand.

In India, 100 percent FDI is allowed in the IT/ITeS sector, while Thailand allows only 49 percent FDI. Due to the FDI restrictions and language barriers, only a few Indian companies operate in Thailand. Some companies operate through local agents and provide services to sectors such as banking and telecommunications. Indian companies mainly engage in software project implementation, training and maintenance in Thailand. They pointed out that there is scope for Indian companies to provide IT/ITeS services in Thailand in sectors such as logistics and supply chain management and content for telecommunications. Survey respondents also pointed out that since the Thai government plays a major role 
in the IT sector, an inter-government agreement between India and Thailand in areas such as e-governance could benefit Indian companies.

People-to-people Connectivity

People-to-people connectivity in terms of easier movement of professionals and workers facilitates bilateral trade and market integration. The movement of professionals is a key component of India's trade agreements, while Thailand seeks market access for certain specialised skills under its trade agreements. These two types of movements are examined below.

Professional services have become an important component of India's services exports and it has the second largest share in India's export basket after IT/ITeS services. The country has a large educated workforce that can provide services at competitive rates. The survey found that the movement of professionals between the two countries is limited primarily due to various restrictions on movement of professionals imposed by the two countries, which include FDI restrictions, nationality and residency requirement and requirement to register with professional bodies. Survey participants pointed out that although the skill levels in professions such as engineering, and management consultancy are higher in India and there is a demand in Thailand for these skills, bilateral trade will not increase unless market access and regulatory barriers to trade are addressed.

Thai professional bodies fear that a large inflow of professionals from India may adversely impact the employment prospects of the local workforce. Some Indian professional bodies such as the Bar Council of India and the Council of Architecture have expressed a similar fear. Thus, professional bodies in both countries lobby against the removal of entry barriers for foreign professionals. Survey participants also pointed out that since the qualification requirements and standards in the two countries differ and they have limited knowledge about each other's market, there is a need for greater interaction and sharing of knowledge among professional bodies. For instance, the Institute Chartered Accountants of India can share information with the Institute of Certified Accountants and Auditors of Thailand.

There is a shortage of management professionals in Thailand and the Institute of Management Consultants of India has expressed an interest in collaborating with the Institute of Management Consultants, Thailand for easier movement of professionals. The Dental Council of India also pointed out that there is scope for mutual recognition agreements (MRAs) between the professional bodies of the two countries for recognition of each other's qualifications in the areas of dentistry and nursing.

Specialised Skills - Thailand is known for its workers with specialised skills such as spa workers. India, too, has workers with specialised skills such as yoga instructors. India and Thailand have developed competence in alternative medicine (for example, ayurveda) and beauty treatments. The two countries share complementary skills and are keen to export such specialised skills to foreign markets. These skills are closely linked to the cultural, tourism and healthcare services sectors.

Thai companies and spa workers are keen to explore the Indian market. The survey found that there is a demand for Thai spa specialists in India. However, due to the minimum salary requirements of US $\$ 2500$ in India, it is not profitable to employ spa specialists from Thailand on work permits, so they usually come on tourist visas for 6 months, which impacts the continuity of their services. It is also a misuse of market entry regulations. The survey participants pointed out that to enhance bilateral trade there should be collaborations between the Indian Spa and Wellness Association and the Thai Spa Association, and between the Association of Beauty Therapy and Cosmetology, India and the Siamese Association of Beauty Therapy, Thailand.

Institutional Connectivity

Institutional connectivity can be at different levels-government-to-government, between professional bodies of the two countries, between industry associations, between government and businesses, and between businesses and businesses. It can be bilateral—between India and Thailand - and regional—between South Asia and ASEAN or between India and ASEAN.

Collaboration and sharing of knowledge and information among the different institutions of the two countries can facilitate market integration and development of value chains. Deeper market integration can happen when professional bodies and other institutions recognise each other's qualifications and standards.

\section{Barriers to Market Integration and Development of Value Chains}

The above discussions highlight that while there is scope for enhancing services trade between India and Thailand, there are several barriers which need to be addressed. The barriers can be general or sector-specific. They can be related to investment or movement of people.

The most important investment barrier faced by companies in each other's' market is the FDI restriction. FDI restrictions in sectors such as multi-brand retail impact establishment of end-to-end value chain in a country like India. 
Multiple regulations, lack of coordination between ministries, issues related to land acquisition, regulatory uncertainties have been identified as other barriers in the two markets. The survey participants highlighted that the reform process in the two countries is slow and their regulatory frameworks are still weak. They gave the example of the slow process of implementation of the single Goods and Services Tax in India, which is crucial for the establishment of a supply chain. In several cases (such as the case of telecommunications in Thailand) foreigners are granted approvals on a case-by-case basis, making the procedure non-transparent.

Multiple documents are required in both countries, which create delays. In the case of India, the quasi-federal governance structure results in differences in regulations and taxes across states. This not only acts as a barrier to the establishment of a smooth pan-India supply chain but also increases the cost of doing business.

Both countries impose several restrictions with respect to short-term employment of foreign nationals. For example, in Thailand, a large number of professions such as engineering, accounting, legal and architectural services are reserved for Thai nationals. In occupations where foreign nationals are permitted to work, a foreign national requires both a work permit and the correct work visa. However, different authorities issue these documents; the work permit is issued by the Ministry of Labour, whereas visas are given by the Ministry of Interior. Further, the Thai work permit allows the applicant to work at the company location listed in the work permit. This is a major barrier for Indian IT companies that send workers on projects basis as at the end of a project, the IT professionals cannot be transferred to another project within the country. Further, the company applying for the work permit is required to hold fully paid-up registered capital of two million Thai Baht $(\$ 56,692)$; if the applicant is married to a Thai national, the required amount is one million Baht (US\$28,346). If the company is registered with the Board of Investment (BoI), it can obtain multiple work permits without increasing the registered capital, depending on the agreement with the BoI, but they need to hold a minimum of one million Baht in registered capital. Foreign business entities can apply their employees for work permit if they bring at least three million baht $(\$ 85,038)$ per employee into the country. ${ }^{8}$

About half of the Indian companies interviewed pointed out that it takes 55-60 days to get a visa for longer stays (a business visa is given on arrival). Moreover, the visa and work permit are usually issued for only one year and can be extended only for another year. Thus, there is a restriction on the length of stay.

Thai specialist workers also find it difficult to enter and work in India. One of the most important barriers to the movement of Thai specialist workers is the minimum salary condition of $\$ 25,000$ per annum imposed on foreign nationals in India. ${ }^{9}$ Thai spa and massage workers pointed out that $\$ 25,000$ per annum is a managerial-level salary and not that of a therapist or a masseuse.

There are some other barriers to services trade. For example, companies from both countries have limited knowledge about each other's market. Companies from Thailand pointed out that due to limited knowledge about the Indian market they find it difficult to identify the right business partner or the right state where they could invest.

While all survey participants felt that reforms and liberalisation will support market integration, industry from the two countries complained that there is limited involvement of different stakeholders, industry bodies and sector experts in the reform process and trade negotiations. The governments in the two countries do not have robust data on bilateral trade in services and this prevents the industry from getting a complete picture of the trade flows and market potential.

\section{Services Value Chains and Trade Agreements}

While most of the above discussed barriers can be addressed through domestic reforms and autonomous liberalisation in India and Thailand, a number of trade facilitation measures can be implemented through trade agreements involving the two countries. India and Thailand are founding members of the WTO and are negotiating multiple trade agreements. A closer look into the previous trade agreements of the two countries highlight how far they can commit beyond their autonomous regimes to provide easier market access to their trading partners and facilitate development of production networks and global value chains. Given that both the countries have imposed a number of restrictions on market access and operation of foreign service providers in their autonomous regime, trade agreements become an important tool for fostering market integration.

\subsection{India and Thailand in Multilateral Trade Agreement - The Doha Round of WTO Negotiations}

The Doha Round of WTO negotiations has not progressed much. Both India and Thailand had submitted their Revised

\footnotetext{
${ }^{8}$ Converted using www.oanda.com at an exchange rate of 1 Thai Baht $=\$ 0.02835$; accessed on June 102016.

9 According to the visa regime in India, a foreigner seeking an employment visa should draw a salary of more than US\$25,000 per annum. However, this condition of an annual floor limit on income does not apply to: (a) ethnic cooks, (b) language teachers (other than English language teachers)/translators, and (c) staff working for the concerned Embassy/High Commission in India.
} 
Offers in the $\mathrm{WTO}^{10}$ and the offers of both countries are below their autonomous level of liberalisation.

Following the MTN.GNS/W/120 classification that is used in the WTO negotiations on services, India offered to undertake commitments in 11 broad services sectors, while Thailand offered to take commitments in 10 broad services sectors. Both countries covered a limited number of sub-sectors within each of these broad categories. Some of the sensitive sectors for Thailand are integrated engineering services, medical and dental services, services provided by midwives, nurses, physiotherapists and para-medical personnel, R\&D services in social sciences and humanities, services related to management consulting, services incidental to energy distribution, placement and supply services of personnel and tourist guide services. The sensitive sectors for India are education services, legal services, postal and courier services and retail trade.

In the WTO, both India and Thailand have taken most favoured nation exemptions to accord preferential treatment to select trading partners. Both India and Thailand are demandeurs of Mode 1 and Mode 4. However, while India demands easier market access for high-skilled people, Thailand focuses on easier movement of specialised skills. Among ASEAN countries, Thailand is less offensive on services negotiations compared to countries such as Singapore, but more offensive than countries such as Malaysia, Indonesia and the Philippines. ${ }^{11}$ Along with other ASEAN countries (except Singapore), it is campaigning for an emergency safeguard mechanism in GATS to protect against a surge of imports in exceptional situations. ${ }^{12}$

\subsection{India and Thailand and Regional Trade Agreements}

The ASEAN services market is not as integrated as the market for goods. The ASEAN Framework Agreement on Services (AFAS) was signed on December 15, 2005, to provide a legal framework that would enable ASEAN member states to progressively liberalise and integrate their services markets. It follows the structure and positive list approach of GATS for scheduling commitments, but it aims to expand the depth and scope of liberalisation beyond GATS. ${ }^{13}$ AFAS also introduced the 'ASEAN Minus X' formula in the implementation of member states' services commitments. ${ }^{14}$ Under this formula, countries that are ready to liberalise a certain service sector may proceed to do so without having to extend the concessions to non-participating countries.

In 2007, ASEAN adopted the ASEAN Economic Community (AEC) Blueprint ${ }^{15}$ to strengthen the institutional framework and have a unified legal identity by putting in place rule-based systems so that the AEC could be established by $2015 .{ }^{16}$ In the area of trade in services, the Blueprint focuses on removing barriers to foreign investment, integrating markets in sectors such as air transport, health, tourism and logistics services and MRAs in professions such as engineering, architectural services and nursing to facilitate easier movement of people within ASEAN. As a member of ASEAN, Thailand is in the process of initiating domestic reforms to meet the regulatory requirements of this agreement.

In South Asia, India along with other SAARC member countries (Afghanistan, Bangladesh, Bhutan, Maldives, Nepal, Pakistan and Sri Lanka) signed the South Asian Association for Regional Cooperation (SAARC) Agreement on Trade in Services (SATIS) at the $16^{\text {th }}$ SAARC Summit held in Thimphu in April 2010 which came into force on November 29, 2012 after ratification by all SAARC member states. At present, negotiations on the Schedule of Specific Commitments of individual SAARC countries are ongoing. ${ }^{17}$

At the $10^{\text {th }}$ ASEAN-India Summit in New Delhi on December 20, 2012, India and ASEAN concluded negotiations for FTAs in services and investment and the agreement was signed in September 2014. ${ }^{18}$ The ASEAN-India Investment and Services Agreement came into force in July 2015. According to the Indian government officials, India and ASEAN member states have taken GATS plus commitments (which implies commitments above the Uruguay Round) in various services sectors and sub-sectors and modes of supply. While each ASEAN member state has tabled an individual schedule of commitments, India has tabled three schedules of commitments - one for the Philippines, one for Indonesia and one for the remaining eight ASEAN member states. India also agreed that in order to increase the participation of least developed countries, no additional requests would be tabled to Cambodia, People's Democratic Republic of Laos, Myanmar and Vietnam. All the three schedules tabled by India are lower than the level of autonomous regime in India.

10 For Thailand's Revised Offer to the WTO, see

http://www.esf.be/pdfs/GATS\%20Revised\%20Offers/Thailand\%20Revised\%20Offer.pdf and for India's revised offer to the WTO, see http://commerce.nic.in/trade/revised_offerl.pdf (accessed on May 10 2016)

11 For details, see Sally (2005).

12 For details, see Sally (2007).

13 http://www.asean.org/6628.htm (accessed on May 26 2016).

14 http://www.aseansec.org/8205.htm (accessed on May 26 2016).

15 http://www.asean.org/21083.pdf (page number 8-11) (accessed on May 26 2016).

16 http://www.asean.org/21082.htm (accessed on May 26 2016).

$17 \mathrm{http} / / /$ saarc-sec.org/areaofcooperation/detail.php?activity_id=46 (accessed on May 26 2016).

18 Available at http://pib.nic.in/newsite/PrintRelease.aspx?relid=109489 (last accessed on May 21 2016.) 
The inability of India and Thailand to go beyond the level of autonomous liberalisation in the ASEAN-India Investment and Services Agreements is a major deterrent to the development of global value chains in services and services market integration. Subsequent to the reduction of tariffs in goods under the India-Thailand Early Harvest and ASEAN-India FTA in goods, a number of Indian companies have established manufacturing units in Thailand and new value chains have developed in trade in goods. However, services value chains have not developed as desired, since both countries continue to impose market access and other barriers.

\subsection{India, Thailand and their Bilateral Trade Agreements}

Thailand's FDI regime is pretty restrictive but the country is willing to go beyond its autonomous regime in bilateral trade agreements, unlike India. For instance, in the agreement with Japan, in sectors such as wholesale trade and retail services that are under List 3 of the Foreign Business Act, B.E. 2543 (1999), ${ }^{19}$ Thailand has allowed foreign participation. Moreover, in sectors such as travel and tourism services, foreign investment has been increased from 49 percent to 60 percent. In the agreement with Australia, Thailand allows 100 percent Australian ownership in general management consulting services. For education services, Thailand permits Australian equity participation up to 60 percent in some specialised tertiary education services. In its autonomous regime, Thailand permits 49 percent foreign ownership in these sectors. India has not gone beyond its autonomous regime in its bilateral comprehensive trade agreements with countries such as Singapore, Japan and the Republic of Korea. However, it has improved its commitments compared to the WTO Revised Offer in sectors such as professional services, R\&D services, telecommunications services, audiovisual services and construction and engineering-related services.

In the case of the movement of natural persons, while India made commitments under all four categories of service suppliers, Thailand has not covered independent professionals. Thailand seems to give preferential treatment to its bilateral trading partners in terms of temporary entry of people. For example, in the Thailand-Australia Free Trade Agreement, Australian business visitors do not require a work permit and can attend or conduct business meetings in Thailand for up to 15 days; this condition does not apply to business visitors from other countries, who require both a visa and a work permit. Thailand also has the provision of an APEC Australian Business Travel Card (ABTC) under the Thailand-Australia Free Trade Agreement. ABTC cardholders are permitted to attend business meetings/seminars or conduct business contracts without engaging in making direct sales of goods to the general public, and they can supply services or can acquire remuneration in Thailand for up to 90 days. Thailand also permits spouses of service suppliers to work as managers, executives or specialists for Thai companies. In its trade agreement, Thailand requests easier movement in specialised skills such as Thai chefs and spa workers.

In its bilateral agreements, India has given commitments in a wide range of professions across four categories of movements, namely, business visitors (BV), ${ }^{20}$ intra-corporate transferees (ICT), ${ }^{21}$ independent professionals (IP) ${ }^{22}$ and contractual service suppliers (CSS). ${ }^{23}$ It seeks market access for professionals. However, Indian commitments do not go beyond the domestic regime or the request that India makes is not beyond the work permit and visa regimes of its trading partners. None of India's trade agreements have provisions for specialised visas or free movements as under North American Free Trade Agreement (NAFTA), nor do India's trade agreements focus on liberalisation of the entire value chain within each professional category. The professional categories that India seeks to liberalise under trade agreements do not match the ILO (International Labour Organization) classifications or any other internationally recognised labour classifications (for details, see Mukherjee and Goyal, 2013).

In its bilateral agreements, India wants liberalisation commitments in knowledge-based services, such as computer-related services, and Modes 4 and 1, while Thailand pushes for movement of specialised skills. In their respective trade agreements, India and Thailand have provisions for co-operation in areas such as science and technology and information communication and technology. Overall, Thailand made commitments to go beyond the autonomous level of liberalisation in its bilateral trade agreements, which can help to facilitate the development of value chains with countries with which it has signed such agreements. Specialised visas under trade agreements can facilitate the movement of people while removal of FDI barriers can lead to free flow of capital. In this context, India has lot to learn from Thailand on how to use the trade agreements to initiate services sector liberalisation.

\section{Conclusions}

Based on the above analysis, this paper found that India and Thailand have the potential to participate in global value

19 In sectors listed in List 3, foreigners are prohibited from operating unless permitted by the Director-General.

20 A person who visits another country for a short duration specifically for business negotiations and/or for preparatory work to establish a presence.

${ }_{21}$ Employee of a company who transferred from the originating country's office to an office of the same company in another country.

22 A self-employed person who entered another country to perform a service on contract basis.

23 Employee of a foreign company who enters another country temporarily in order to perform a service pursuant to a contract. 
chains by integrating their services sector. While the two countries impose several restrictions on services trade, these can be addressed through domestic reforms and commitments under trade agreements that go beyond the level of autonomous liberalisation. Ideally, a bilateral trade agreement should go beyond the domestic regime to facilitate market integration. Nevertheless, if it even binds the existing regime, it provides operational certainty to businesses, since both countries will find it difficult to roll back the existing regime. Such operational certainty is important in countries such as India and Thailand that frequently change their regulatory regime.

In the case of India, commitments under trade agreements in services have always been lower than the level of autonomous liberalisation. Due to its own restrictive approach in trade negotiations, India has not been able to bargain aggressively for its services exporters. Thailand seems to have a more restrictive autonomous FDI regime than India but it is willing to go beyond the autonomous regime in bilateral trade agreements, using it as an important tool for negotiations. Since both India and Thailand are negotiating mega trade agreements, such as the RECP, they need to have well-defined timeframes for implementing domestic reforms, which will enable them to leverage on their strengths and negotiate aggressively for greater market access and removal of barriers to services trade. At the same time, India and Thailand have to implement a sound regulatory framework that enables foreign companies to operate in a transparent and non-discriminatory environment. Commitments under trade agreements may help speed up the domestic reform process in the two countries thereby integrating the services markets in South and Southeast Asia.

This paper also highlights that India and Thailand have strong complementarities in trade in services. However, much of this remains unexplored due to barriers in both markets. If the barriers are removed, it will lead to more bilateral trade and development of services value chains. While for Thailand, the key driver of domestic reforms is the ASEAN market integration of 2015, in India it is the fear of slowdown in growth rate. The pace of reforms in the two markets is relatively slow, especially compared with other Southeast Asian countries. There is an urgent need to prioritise and implement reforms especially those related to the removal of FDI restrictions and regulatory hurdles in services.

An important issue raised in this paper is the lack of data on bilateral trade flows which makes it difficult to analyse the recent trends and developments in bilateral trade. Bilateral trade data is also needed by companies in both countries to understand the market potential. It is, therefore, important for the government of the two countries to collect the bilateral trade data and make it public. As services are becoming an important component of the global value chains, there is need for robust data on value added by services. For this, there can be enterprise surveys on value added by services in exports.

\section{References}

ADB (2009). Designing and Implementing Trade Facilitation in Asia and the Pacific. ADB and UNESCAP, Manila.

Asian Development Bank (ADB). (2008). Transport and Trade Facilitation in the Greater Mekong Subregion - Time to Shift Gears. Evaluation Study, Operations Evaluation Department, Asian Development Bank, Manila, December 2008 accessible at http://www.adb.org/sites/default/files/evaluation-document/35393/files/sap-reg-2008-86.pdf (accessed on June 8, 2016)

Baldwin, R. E. (2006). Managing the Noodle Bowl: The Fragility of East Asian Regionalism. Discussion Paper No. 5561, Centre for Economic Policy Research, London; available at https://www.sussex.ac.uk/webteam/gateway/file.php?name=7.pdf\&site $=261 \quad$ accessed $\quad$ on June 8, 2016. http://dx.doi.org/10.1142/s0217590808003063

Board of Investment (BoI) (2010). Foreign Investor Confidence Survey Report - Summary Report. Thailand accessible at http://www.boi.go.th/english/download/news/1851/summary_english.pdf (accessed on June 8, 2016)

Brockman, J. D., \& Sherry, S. (2012). Implications for $21^{\text {st }}$ Century Trade and Development of the Emergence of Services Value Chain. International Centre for Trade and Sustainable Development, Geneva.

DeBacker, K., \& Miroudot, S. (2013). Mapping Global Value Chains. OECD Trade Policy Papers, 159, OECD Publishing http://dx.doi.org/10.1787/5k3v1trgnbr4-en

Fink, C., \& Martın, M. (2008). East Asian Free Trade Agreements in Services: Key Architectural Elements. Journal of International Economic Law, 11(2), 263-311. http://dx.doi.org/10.1093/jiel/jgn010

Institute of Developing Economies (IDE)-JETRO and WTO (2011). Trade Patterns and Global Value Chains in East Asia: From Trade in Goods to Trade in Tasks, Geneva available at https://www.wto.org/english/res_e/booksp_e/stat_tradepat_globvalchains_e.pdf (accessed on June 6, 2016)

Kawai, M., \& Ganeshan, W. (2009). The Asian "Noodle Bowl": Is it Serious for Business?. Asian Development Bank Institute Working Paper Series, Number 136, April 2009; available at http://www.adb.org/sites/default/files/publication/155991/adbi-wp136.pdf accessed on June 8, 2016. http://dx.doi.org/10.2139/ssrn.1392073 
Kimura, F., T. K., \& Umezaki, S. (2011). ASEAN-India Connectivity: A Regional Framework and Key Infrastructure Projects. in F. Kimura and S. Umezaki (Eds.), ASEAN-India Connectivity: The Comprehensive Asia Development Plan, Phase II (pp.1-56). ERIA Research Project Report 2010-7, Jakarta: ERIA.

López, A., Andrés, N., \& Daniela, R. (2011). Global Value Chains, Services Offshoring and the Role of Human Resources: Lessons from Argentina. Universidad Nacional de General Sarmiento.

Mukherjee, \& G. (2013). Examining Mode 4 Commitments in India and the EU's Agreements: Implication for the India-EU BTIA. European University Institute, Migration Policy Centre; CARIM-India Research Report, 2013.

Ohlin, B. (1933). Interregional and International Trade. Cambridge: Harvard University Press.

Prabir, D. (2011). Trade Facilitation in India: An Analysis of Trade Processes and Procedures. Asia-Pacific Research and Training Network on Trade, Working Paper Series, 95. http://dx.doi.org/10.18356/3e4ab331-en

Rubalcaba, L., Gallego, J., \& Hipp, C. (2011). Organisational Innovation, Service Innovation, and the Value Chain: New Trends and Policy Implications. Input Paper for the Workshop on January 25 - Task 5, Europe INNOVA Sectoral Innovation Watch, European Commission, January.

Sally, R. (2005). Thailand's New FTAs and its Trade Policies Post Asian Crisis: An Assessment. Mimeo, www2.lse.ac.uk/.../centresandunits/ITPU/docs/sallythailand.doc

Sally, R. (2007). Thai Trade Policy: From Non-discriminatory Liberalisation to FTAs. The World Economy, 30(10), 1594-1620. http://dx.doi.org/10.1111/j.1467-9701.2007.01014.x

United Nations (2014). Enhancing Regional Connectivity: Towards a Regional Agreement for the Facilitation of Cross-border Paperless Trade. Studies in Trade and Investment, United Nations, Thailand.

World Bank (2013). World Development Indicators - 2013. The World Bank, Washington D.C., USA http://databank.worldbank.org/data/download/WDI-2013-ebook.pdf accessed on June 8, 2016.

World Economic Forum (2012). The Shifting Geography of Global Value Chains: Implications for Developing Countries and Trade Policy. Global Agenda Council on the Global Trading System. http://dx.doi.org/10.7871/2291-4110.1005

World Trade Organization (WTO) (2014). International Trade Statistics 2014. WTO, Geneva. accessible at https://www.wto.org/english/res_e/statis_e/its2014_e/its2014_e.pdf accessed on June 8, 2016.

\section{Copyrights}

Copyright for this article is retained by the author(s), with first publication rights granted to the journal.

This is an open-access article distributed under the terms and conditions of the Creative Commons Attribution license which permits unrestricted use, distribution, and reproduction in any medium, provided the original work is properly cited. 